Volume 3, No. 2 Januari 2020

\title{
PENINGKATAN KETERAMPILAN GURU PAUD DALAM MENYUSUN PROGRAM PEMBELAJARAN INDIVIDUAL ANAK BERKEBUTUHAN KHUSUS DI PAUD PERMATA BUNDA
}

\author{
Lutfi Isni Badiah, Muhammad Nurrohman Jauhari, Sambira \\ Program Studi Pendidikan Khusus \\ Universitas PGRI Adi Buana Surabaya \\ lutfi@unipasby.ac.id \\ mnjauhari@unipasby.ac.id \\ sam.mambela@gmail.com
}

\begin{abstract}
ABSTRAK
Pendidikan inklusi sudah dilaksanakan pada tingkat Pendidikan Anak Usia Dini. Pendidikan inklusi merupakan pendidikan yang memberi kesempatan kepada anak berkebutuhan khusus untuk belajar bersama dengan peserta didik lain disekolah umum. Mereka diberikan kesempatan dalam mengikuti proses belajar mengajar, interaksi sosial dan dalam kegiatan sekolah

Pada Tingkat Pendidikan Anak Usia Dini banyak terdapat anak berkebutuhan khusus antara lain anak yang memiliki hambatan perilaku, cerdas istimewa dan bakat istimewa dan anak autis. Permasalahan yang terjadi banyak guru PAUD yang belum mengetahui tentang penyusunan program pembelajaran individual. Maka dari itu guru memerlukan pelatihan dalam melakukan penyusunan program pembelajaran individual.

Pelaksanaan kegiatan dilakukan dalam 3 tahapan antara lain perencanaan, pelaksanaan dan evaluasi, subjek dari kegiatan ini sebanyak 10 guru Pendidikan Anak Usia Dini di Permata Bunda. Dari hasil kegiatan tersebut dapat disimpulkan bahwa adanya peningkatan pemahaman dan pelaksanaan peserta dalam menyusun program pembelajaran individual.
\end{abstract}

Kata kunci: Guru PAUD, Program Pembelajaran Individual 


\section{A. Pendahuluan}

Pendidikan inklusi merupakan pendidikan yang memberi kesempatan kepada anak berkebutuhan khusus untuk belajar bersama dengan peserta didik lain disekolah umum. Mereka diberikan kesempatan dalam mengikuti proses belajar mengajar, interaksi sosial dan dalam kegiatan sekolah. Menurut (Elisa \& Wrastari, 2013) Pendidikan inklusi merupakan pemenuhan hak azasi manusia dengan menghilangkan diskriminasi dalam dunia Pendidikan tanpa adanya pengecualian yang memberikan tujuan untuk meningkatkan potensi peserta didik dalam meningkatkan kemampuannya dalam bidang akademik dan non akademik. Di Indonesia Pendidikan inklusi dimulai pada tahun 2004 dalam lokakarya nasional untuk menentukan perancangan Pendidikan inklusi. Kemudian setelah itu dibuat Permendinas yaitu berdasarkan (Kementerian Pendidikan Nasional Republik Indonesia, 2009) tentang Pendidikan inklusi bagi peserta didik berkebutuhan khusus, dalam permendiknas tersebut dijelaskan tentang peserta didik berkebutuhan khusus, peraturan tentang setiap kota atau kabupaten memiliki satu sekolah inklusi

Pada awal implementasi pendidikan inklusi dilaksanakan pada tingkat Sekolah Dasar, Sekolah Menengah Pertama, kemudian dilanjutkan pada Sekolah Menengah Atas dan Sekolah Menengah Kejuruan. Setelah itu dilaksanakan pada tingkat Pendidikan Anak Usia Dini. Peserta didik berkebutuhan khusus yang diterima disekolah inklusi antara lain tunanetra, tunarungu, tunadaksa, tunagrahita, autis kesulitan belajar, bakat istimewa cerdas istimewa dan lamban belajar yang tidak disertai hambatan intelegensi. Menurut (Salamah, 2015) anak berkebutuhan khusus adalah anak yang memiliki hambatan pengelihatan, hambatan pendengaran, hambatan motorik, hambatan intelgensi, dan hambatan perilaku. Identifikasi dan asesmen merupakan hal yang penting dalam mengetahui hambatan yang dimiliki oleh anak dan memberikan penanganan yang sesuai dengan kebutuhan anak berkebutuhan khusus.

Berdasarkan hasil observasi tim ditemukan pada pendidikan anak usia dini (PAUD) banyak terdapat anak berkebutuhan khusus antara lain anak yang memiliki hambatan perilaku, cerdas istimewa dan bakat istimewa dan anak autis. hal tersebut dikarenakan kurangnya deteksi dini yang tidak berjalan dengan baik. Dalam hal ini guru PAUD diwajibkan untuk mengetahui layanan akademik dan non akademik dalam memberikan layanan yang sesuai dengan anak. Pengetahuan guru dalam membuat rancangan atau rencana pembelajaran harus melihat hambatan yang dimiliki oleh anak

Guru PAUD memerlukan Program Pembelajaran Individual (PPI) dalam memberikan layanan yang sesuai bagi anak berkebutuhan khusus, PPI disusun oleh guru, orangtua dan 
terapis, oleh karena itu guru PAUD harus memiliki keterampilan dalam menyusun PPI tersebut. PPI adalah program pembelajaran individual yang merujuk pada program pembelajaran yang disesuaikan dengan kemampuan individu (Jayanti, 2014)

\section{B. Metode Pelaksanaan}

Pelatihan merupakan bentuk kegiatan yang dilaksanakan dalam pengabdian kepada masyarakat dalam meningkatkan keterampilan guru PAUD dalam menyusun program pembelajaran individual bagi siswa berkebutuhan khusus di PAUD Permata Bunda. Subjek penelitian ini adalah semua guru PAUD Permata Bunda. Tahapan tersebut dibagi menjadi 3 tahap, antara lain

1. Perencanaan

Tahapan perencanaan ini dilakukan untuk mengetahui pentingnya pelatihan penyusunan PPI bagi guru PAUD di Permata Bunda, langkah dalam perencanaan antara lain:

a. Melakukan survei tempat

b. Melakukan observasi dan wawancara untuk mengetahui permasalahan yang dihadapi guru PAUD

c. Merumuskan metode pelaksanaan pelatihan

d. Membuat modul pelatihan berdasarkan hasil observasi dan wawancara

2. Pelaksanaan

Pada tahap pelaksanaan ini menggunakan metode pre-test dan post-test. (Sugiyono, 2015) desain penelitian yang digunakan untuk mengetahui pengaruh perlakuan terhadap sebuah kondisi yang dapat dikendalikan. Dengan tahap pretest (test awal), treatment (perlakuan) dan post-test (tes akhir). Kegiatan ini dilakukan dalam 3 kali pertemuan dengan rincian:

a. Pelaksanaan pre-test (tes awal)

b. Pelatihan (treatmeant)

c. Pelaksanaan post-test (tes akhir)

3. Evaluasi

Tahapan evaluasi bertujuan untuk memberikan masukan berdasarkan hasil tes akhir yang sudah dilakukan oleh guru PAUD

\section{Hasil dan Pembahasan}

Kegiatan pengabdian kepada masyarakat yang berjudul Peningkatan Keterampilan Guru PAUD Dalam Menyusun Program Pembelajaran Individual Anak Berkebutuhan Khusus di PAUD Permata Bunda didapatkan hasil sebagai berikut:

1. Identifikasi masalah

Identifikasi awal dilakukan dengan melaksanakan observasi dan wawancara kepada 10 guru PAUD Permata Bunda. Dari hasil observasi dan wawancara tersebut ditemukan adanya permasalahan guru PAUD Permata Bunda dalam menyusun program pembelajaran individual untuk anak berkebutuhan khusus yang berada di PAUD Permata Bunda. Penyebab dari permasalahan itu adalah kurangnya pengetahuan guru dalam menyusun PPI, oleh 
Volume 3, No. 2 Januari 2020

sebab itu diperlukan adanya pelatihan bagi guru PAUD Permata Bunda dalam menyusun PPI bagi anak berkebutuhan khusus.

2. Menentukan metode pelaksanaan pelatihan

Strategi atau metode yang digunakan dalam pengabdian kepada masyarakat ini adalah metode lecture (ceramah) yang dikombinasikan dengan metode demonstration. (Fatimah, 2018) Metode lecture (ceramah) adalah penyampaian materi oleh tutor secara lisan kepada peserta. Sedangkan (Ginting \& Zulmiyetri, 2018) metode demonstration merupakan penyampaian materi dengan menggunakan cara mempraktikkan secara lansung kepada peserta.

3. Pembuatan modul pelatihan

Modul pelatihan dibuat berdasarkan hasil wawancara yaitu permasalahan guru PAUD Permata Bunda dalam menyusun PPI bagi anak berkebutuhan khusus. Modul tersebut berisi materi tentang : Anak Berkebutuhan Khusus, Layanan kompensatoris anak berkebutuhan khusus, Ruang Lingkup PPI, Tujuan dan Manfaat, Komponen PPI dan Langkah-langkah penyusunan PPI

4. Pelaksanaan pre-test

Pelaksanaan pre-test dilakukan dengan cara memberikan tes tulis bagi guru PAUD Permata Bunda pada tanggal 9 Desember 2019.
Hasil dari pre-test dari 10 peserta didapatkan $50 \%$ guru mengetahui tentang penyusunan PPI dan sebagian guru tidak memahami bagaimana penyusunan PPI, hal tersebut disebabkan karena beberapa guru belum pernah mendapatkan pelatihan atau materi tentang penyusunan PPI bagi anak berkebutuhan khusus

5. Pelaksanaan pelatihan

Kegiatan pelatihan bagi guru PAUD dilaksanakan di ruang kelas A PAUD Permata Bunda pada tanggal 9 Desember 2019 dengan rundown acara sebagai berikut:

Table 1. Rundown kegiatan

\begin{tabular}{|c|c|c|c|}
\hline No & Waktu & Uraian Materi & Pemateri \\
\hline 1. & $\begin{array}{l}07.30- \\
07.45\end{array}$ & - Registrasi & Panitia \\
\hline 2. & $\begin{array}{l}07.45 \\
08.00\end{array}$ & - Pembukaan & Panitia \\
\hline 3. & $\begin{array}{l}08.00- \\
09.00\end{array}$ & - Pre-test & Panitia \\
\hline 4. & $\begin{array}{l}09.00 \\
10.00\end{array}$ & $\begin{array}{l}\text { - Sesi } 1 \text { : Anak } \\
\text { berkebutuhan } \\
\text { khusus, } \\
\text { Layanan } \\
\text { kompensatoris }\end{array}$ & $\begin{array}{l}\text { Sambira, } \\
\text { M.Pd }\end{array}$ \\
\hline 5. & $\begin{array}{l}10.00 \\
12.00\end{array}$ & $\begin{array}{l}\text { Sesi } 2 \text { : Ruang } \\
\text { lingkung PPI, } \\
\text { Tujuan dan } \\
\text { manfaat PPI }\end{array}$ & $\begin{array}{l}\text { Lutfi Isni } \\
\text { Badiah, } \\
\text { M.Pd }\end{array}$ \\
\hline 6. & $\begin{array}{l}12.00 \\
13.00\end{array}$ & - Istirahat & Panitia \\
\hline 7. & $\begin{array}{l}13.00 \\
15.00\end{array}$ & $\begin{array}{l}\text { - Sesi } 3 \text { : } \\
\text { komponen PPI, } \\
\text { langkah } \\
\text { penyusunan PPI }\end{array}$ & $\begin{array}{l}\text { M.N. } \\
\text { Jauhari, } \\
\text { M.Pd }\end{array}$ \\
\hline 8. & $\begin{array}{l}15.00 \\
15.30\end{array}$ & - Penutupan & Panitia \\
\hline
\end{tabular}


Penyampaian sesi 1 pertama tentang anak berkebutuhan khusus dan layanan kompensatoris dilakukan oleh Sambira, M.Pd, dalam sesi 1 suasana pelatihan sangat interaktif antara pemateri dengan guru PAUD. Banyak guru PAUD yang bertanya tentang anak berkebutuhan khusus dan layanan yang harus diberikan oleh guru kepada anak berkebutuhan khusus. Kemudian pada sesi 2 materi tentang ruang lingkup, tujuan dan manfaat PPI oleh Lutfi Isni Badiah, M.Pd, banyak guru yang bertanya tentang kebutuhan yang harus disiapkan dalam penyusunan PPI. Pada sesi 3 tentang komponen dan langkah penyusunan PPI yang disampaikan oleh M.N. Jauhari, M.Pd, materi tersebut banyak melakukan praktik langsung dalam menyusun PPI bagi anak berkebutuhan khusus. Setelah semua materi disampaikan guru diberikan tugas untuk menyusun PPI.

6. Pelaksanaan post-test

Pelaksanaan post-test dilakukan dengan cara memberikan tes tulis kepada guru PAUD Permata Bunda pada tanggal 14 Desember 2019. Hasil dari pre-test dari 10 peserta didapatkan $80 \%$ guru mengetahui tentang bagaimana penyusunan PPI bagi anak berkebutuhan khusus. Berdasarkan hal tersebut kemampuan guru dalam menyusun PPI bagi anak berkebutuhan khusus meningkat $30 \%$ dari hasil pre-test dengan hasil $50 \%$.

7. Evaluasi

Evaluasi kegiatan dilaksanakan pada tanggal 14 Desember 2019 setelah diadakannya post-test. Dalam kegiatan evaluasi guru mengumpulkan tugas penyusunan PPI kepada panitia. Setelah itu panitia dan 3 pemateri mengadakan diskusi untuk membahas hasil dari post-test dan tugas. Kemudian hasil tersebut disampaikan oleh pemateri sesi 3 kepada guru PAUD Permata Bunda. Dari hasil tersebut pemateri memberikan masukan kepada guru PAUD Permata Bunda tentang penjabaran kebutuhan anak berkebutuhan khusus, hal ini dikarenakan beberapa guru mengalami kesulitan dalam menentukan kebutuhan yang akan diberikan kepada anak berkebutuhan khusus.

\section{Kesimpulan}

Berdasarkan hasil kegiatan yang sudah dilaksanakan dapat disimpulkan bahwa Peserta memiliki antusias terhadap materi yang disampikan, hal tersebut terlihat dengan keaktifan peserta dalam proses pelatihan serta banyaknya pertanyaan yang diajukan oleh peserta. Dari hasil penilaian pretest, post-test dan tugas terlihat bahwa adanya peningkatan keterampilan guru 
PAUD dalam menyusun program pembelajaran individual anak berkebutuhan khusus di PAUD Permata Bunda. Hal tersebut terlihat dari hasil pre-test 50\% meningkat menjadi $80 \%$ pada saat post-test.

\section{Daftar Pustaka}

Elisa, S., \& Wrastari, A. T. (2013). Sikap guru terhadap pendidikan inklusi ditinjau dari faktor pembentuk sikap. Jurnal Psikologi Perkembangan Dan Pendidikan, 2(01), 1-10.

Fatimah, R. (2018). Pengaruh Implementasi Metode Ceramah Pada Pembelajaran Pendidikan Agama Islam Dalam Perspektif Siswa Terhadap Minat Belajar Siswa Di Smk Ma'arif 2 Sleman. Ginting, S., \& Zulmiyetri, Z. (2018). Efektifitas Metode Demonstrasi dalam Meningkatkan
Keterampilan Membuat

Smoothies bagi Anak Tunarungu. Jurnal Penelitian Pendidikan Khusus, 6(2), 37-42.

Jayanti, D. D. (2014). Strategi Optimalisasi Potensi Siswa Berkebutuhan Khusus Melalui Program Pembelajaran Individual. Akademika, 8(2), 222-230.

Kementerian Pendidikan Nasional Republik Indonesia. (2009). Permendiknas 70 Tahun 2009 tentang Pendidikan Inklusif. Permendiknas 70 Tahun 2009 Tentang Pendidikan Inklusif.

Salamah, U. (2015). Kesiapan Guru Kelas Dalam Menangani Anak Berkebutuhan Khusus di SD N Pojok Kabupaten Sleman. Basic Education, 4(13).

Sugiyono, P. D. (2015). Metode penelitian dan pengembangan. Res. Dev. D, 2015, 39-41. 